\title{
Cytotoxic effects of free fatty acids on phytoplankton algae and cyanobacteria
}

\author{
Jiunn-Tzong $\mathrm{Wu}^{\mathrm{a}, \mathrm{b}, *}$, Yin-Ru Chiang ${ }^{\mathrm{a}}$, Wen-Ya Huang ${ }^{\mathrm{a}}$, Wann-Neng Jane ${ }^{\mathrm{c}}$ \\ ${ }^{a}$ Research Center for Biodiversity, Academia Sinica, Nankang, Taipei 115, Taiwan \\ ${ }^{\mathrm{b}}$ Institute of Ecology and Evolutionary Biology, National Taiwan University, Taipei 106, Taiwan \\ ${ }^{\mathrm{c}}$ Institute of Plant and Microbial Biology, Academia Sinica, Taipei 115, Taiwan
}

Received 27 July 2006; received in revised form 27 September 2006; accepted 29 September 2006

\begin{abstract}
Some free fatty acids are toxic to phytoplankton, and the toxic effects are multiple. However, precisely how they kill phytoplankton is debatable. Here we show that fatty acids result in damage to plasma membranes, which might account for their lethal effects on phytoplankton. In this study, we used two chlorophytes (Chlorella vulgaris Beij. and Monoraphidium contortum (Thur.) Kom.-Legn.) and a cyanobacterium (Anabaena P-9) as test organisms. When these organisms were treated with deleterious concentrations of fatty acids, a remarkable elevation of extracellular potassium $\left(\mathrm{K}^{+}\right)$was detected in the culture medium; this indicates that leakage of intracellular $\mathrm{K}^{+}$occurred as a result of damage to the plasma membranes. Exposure to unsaturated fatty acids resulted in higher levels of leaked $\mathrm{K}^{+}$than did exposure to saturated ones, and levels of leakage displayed a positive correlation with the susceptibility of the growth of organisms to fatty acids. Stressed phytoplankton cells also exhibited cell lysis followed by free release of phycobilins. The sequence of cytotoxic effects elucidated here suggests that fatty acids primarily affect the plasma membranes, leading to a change in membrane permeability and dissociation of phycobilins from the thylakoids. Severe damage to the plasma membranes would give rise to a disruption of the stressed cells.
\end{abstract}

(C) 2006 Elsevier B.V. All rights reserved.

Keywords: Fatty acid; Cytotoxic effect; Cell lysis; Membrane damage; Potassium leakage

\section{Introduction}

Certain free fatty acids produced by algae exert inhibitory effects on a variety of aquatic organisms (Spruell, 1984; Ohta et al., 1995; Ikawa et al., 1996; Kamaya et al., 2003; Mundt et al., 2003) and may play an important role in the interaction between organisms and in the succession of certain phytoplankton species in aquatic ecosystems (Keating, 1977, 1978; Cembella, 2003; Gross, 2003). Jüttner (2001) showed that fatty acids can act as a defense substance against grazers. In fact, numerous researchers have suggested that fatty acids might serve as allelochemicals to affect aquatic organisms (McCracken et al., 1980; Entzeroth et al., 1985; Kakisawa et al., 1988; Suzuki et al., 1996; Chiang et al., 2004).

Allelochemicals can interfere with a variety of processes in organisms (Einhellig, 2001). How allelochemicals act depends

\footnotetext{
* Corresponding author at: Research Center for Biodiversity, Academia Sinica, Nankang, Taipei 115, Taiwan. Tel.: +886 2 27899590x451; fax: +886227893147 .

E-mail address: jtwu@gate.sinica.edu.tw (J.-T. Wu).
}

on the kind of compound; they can inhibit protein or enzyme activity, damage cell membranes, change physiological functions, and lyse target cells (Legrand et al., 2003). The action modes can be multiple or synergistic, making it sometimes difficult to diagnose them (Einhellig, 2001).

In algae, the most allelopathically active compounds inhibit either enzyme activity or photosynthesis (Friend and Hawcroft, 1967; Cohen et al., 1969; Siegenthaler, 1973), particularly electron transport in photosystem II (Venediktov and Krivoshejeva, 1983; Warden and Csatorday, 1987). However, our preliminary study indicated that the inhibition of photosynthesis was not lethal to phytoplankton. In fact, the phytoplankton managed to survive even when photosystem II had been fully inhibited by the presence of 3-(3,4-dichlorophenyl)-1,1-dimethylurea (DCMU) (Chiang, 2002). Thus, the lethality of fatty acids probably cannot be attributed to their inhibitory effect on photosynthesis. Herein we studied other modes of action that might explain the lethal effect of fatty acids on phytoplankton. Using two eukaryotic algae and a cyanobacterium as test organisms, we explored the cytotoxic effects of fatty acids on phytoplankton. 


\section{Materials and methods}

\subsection{Algal and cyanobacterial strains and cultivation}

We used two chlorophytes, Chlorella vulgaris Beij. and Monoraphidium contortum (Thur.) Kom.-Legn., and a cyanobacterium, Anabaena P-9, as test organisms. The chlorophytes were isolated from Lake Li-yu in Taiwan, and the cyanobacterium was obtained from Prof. F. Jüttner of the University of Zürich, Switzerland. The chlorophytes were cultivated in the medium of Kuhl (1962) and the cyanobacterium in the medium described by Todorova and Jüttner (1996). All cultures were kept at $25^{\circ} \mathrm{C}$ under an illumination of approximately $400 \mu \mathrm{mol} \mathrm{m}{ }^{-2} \mathrm{~s}^{-1}$ with a light:dark cycle of $14: 10 \mathrm{~h}$. To maintain log-growing cultures, the density of cultures was kept at $5-20 \mu \mathrm{g} \mathrm{chl} \mathrm{L}{ }^{-1}$ by diluting every 2 days.

\subsection{Toxicity test}

The median effective concentration $\left(\mathrm{EC}_{50}\right)$ for inhibition of cell growth, determined by a moving average method and calculated with the help of the software Softtox 1.1 (WindowChem Software ${ }^{\mathrm{TM}}$, Inc., Fairfield, CA, USA) was employed to designate the toxicity to the tested organisms. The calculation was based on the decrease rate of chlorophyll $a$ content over a $24 \mathrm{~h}$ test time. The unit for $\mathrm{EC}_{50}, \mathrm{mg} \mathrm{mL}^{-1}$, was given in terms of dry weight of B. braunii. Statistical calculation of these values was based on at least three repeated tests. Each test was conducted with three replicate cultures. A simple ANOVA was applied to test the significance of difference of means between datasets.

\subsection{Measurement of $\mathrm{K}^{+}$leakage and determination of $\mathrm{K}^{+}$ concentration}

The test organisms were harvested by centrifugation $\left(3000 \times g, 10 \mathrm{~min}, 25^{\circ} \mathrm{C}\right)$ and resuspended in $\mathrm{K}^{+}$-free culture medium. This procedure was performed thrice to get a baseline concentration for $\mathrm{K}^{+}$in the extracellular medium. The density of cultures was then taken to a final concentration of approximately $8-12 \mathrm{mg} \mathrm{chl} \mathrm{L}^{-1}$. Subsequently, the cultures were incubated at $25^{\circ} \mathrm{C}$ for $1 \mathrm{~h}$ before being subjected to the treatment of various concentrations of fatty acid. After treatment, algal cells in the culture were removed by filtration through a glass fiber membrane (Whatman GF/F, Maidstone, England), and the $\mathrm{K}^{+}$ concentrations in the filtrates were measured with an atomic absorption spectrophotometer (AAS, Perkin-Elmer 2380, Norwalk, CN, USA). The net increment in extracellular $\mathrm{K}^{+}$concentration in response to the fatty acid treatment was calculated, using the amount of extracellular $\mathrm{K}^{+}$concentration before treatment as a baseline. To measure the total intracellular $\mathrm{K}^{+}$content, algal cells were heated to $100^{\circ} \mathrm{C}$ for $10 \mathrm{~min}$ and then the cell-free supernatant was obtained by centrifugation $(3000 \times g, 10 \mathrm{~min})$ for the determination of $\mathrm{K}^{+}$concentration by AAS.

Authentic fatty acids - including oleic acid (OA), linoleic acid (LA), alpha-linolenic acid (LNA), palmitic acid (PA), stearic acid (SA), eicosapentaenoic acid (EPA), docosahexaenoic acid
(DHA), lauric acid (LRA), and myristic acid (MA) - were purchased from Sigma Co. (St. Louis, MO, USA).

\subsection{Quantification of pigment concentrations}

The concentration of chlorophyll $a$ in the cultures was measured using acetone extract and a Turner fluorometer (Sunnyvale, CA, USA) after phytoplankton cells were harvested by centrifugation $(3000 \times g, 10 \mathrm{~min})$ and extracted with aqueous acetone solution (80\%). The concentrations of phycobilins in the extracellular medium were estimated by measuring the extinction of cell-free filtrates at 562,615 , and $652 \mathrm{~nm}$. We used the equations of Bennett and Bogorad (1973) to calculate pigment concentrations.

\subsection{Preparation of samples for transmission electron microscopic (TEM) observation}

To examine the ultrastructural changes in Anabaena P9 cells after treatment with deleterious doses of fatty acids, $0.178 \mu \mathrm{mol} \mathrm{L}^{-1} \mathrm{LA}$ was added to cultures. After addition of LA, samples at $0,15,30,60$, and $120 \mathrm{~min}$ were harvested by rapid centrifugation $(15,000 \times g, 4 \mathrm{~min})$ and resuspended in the fixation medium containing $2.5 \%$ glutaraldehyde and $4 \%$ paraformaldehyde in $0.1 \mathrm{M}$ sodium phosphate buffer $(\mathrm{pH}$ 7.0) at room temperature for $1 \mathrm{~h}$. After three 20-min intervals of rinsing with the same buffer, the samples were post-fixed in $1 \% \mathrm{OsO}_{4}$ in the same buffer for $1 \mathrm{~h}$ at room temperature; they were then rinsed again in fresh buffer for three 20-min intervals. Subsequently, samples were dehydrated in an acetone series, embedded in Spurr's resin, and sectioned with a Leica EM UC6 ultramicrotome (Vienna, Austria). The ultra-thin sections $(70-90 \mathrm{~nm})$ were stained with uranyl acetate and lead citrate. A Philips CM 100 TEM (Eindhoven, Holland) at $80 \mathrm{kV}$ was used for viewing.

\section{Results}

\subsection{Toxicity of fatty acids}

The toxic effects of different fatty acids on the either tested chlorophytes varied. Among the nine fatty acids studied, higher toxicity (i.e., lower $\mathrm{EC}_{50}$ ) was detected for $\mathrm{C}_{18}$-fatty acids, including OA, LA, and LNA, with the highest toxicity displayed by LNA; LRA and MA displayed the lowest toxicity (Table 1). Fatty acids with a high degree of saturation in the C-chain exhibited lower toxicity. Compared with $C$. vulgaris, Anabaena P-9 displayed a similar susceptibility to the fatty acids tested (data not shown).

\subsection{Effect of fatty acids on $K^{+}$leakage}

When a lethal dose of LNA $\left(0.36 \mathrm{mmol} \mathrm{L}^{-1}\right)$ was added to the tested cultures, the concentration of $\mathrm{K}^{+}$in the culture medium increased substantially and immediately, indicating $\mathrm{K}^{+}$leakage from cells to the surrounding medium (Fig. 1). The leakage was pronounced during the first $20 \mathrm{~min}$ and plateaued thereafter. The 


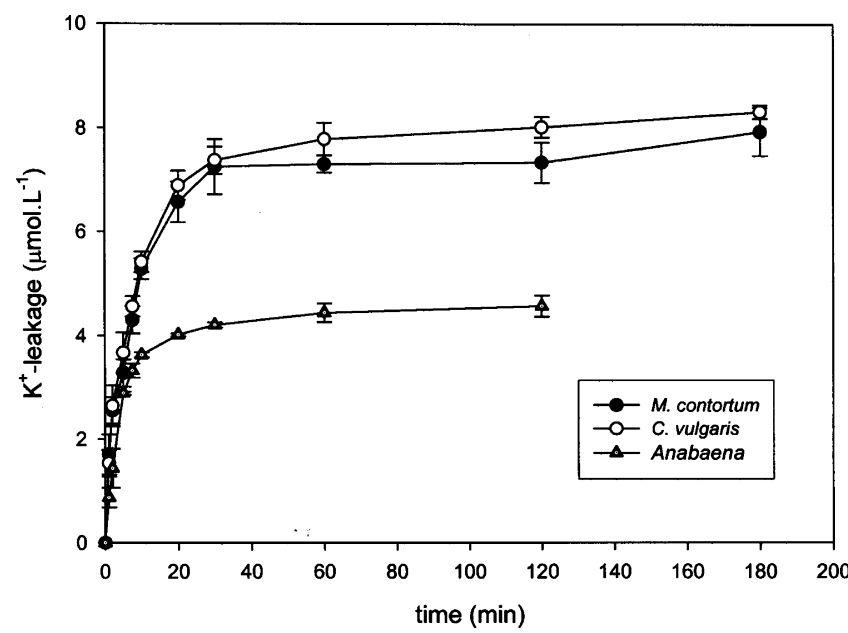

Fig. 1. Time course of $\mathrm{K}^{+}$-leakage in Monoraphidium contortum, Chlorella vulgaris, and Anabaena P-9 cultures as a response to treatment with $0.359 \mathrm{mmol} \mathrm{L}^{-1} \tilde{\alpha}$-linolenic acid. The density of culture was $8.5 \pm 1.5 \mu \mathrm{g}$

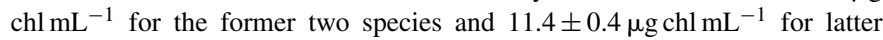
one.

maximum level of released $\mathrm{K}^{+}, 0.038 \pm 0.004 \mathrm{fmol} \mathrm{K}^{+}$cell $^{-1}$, was as high as $12 \%$ of the intracellular total of C. vulgaris, which was estimated by killing the cells with heating at $100^{\circ} \mathrm{C}$ for $10 \mathrm{~min}$. Similar results were obtained for M. contortum.

A similar time course of $\mathrm{K}^{+}$leakage was detected in Anabaena P-9 following treatment with deleterious doses of fatty acids (Fig. 1). However, this species differed from the chlorophytes in releasing lower level of $\mathrm{K}^{+}$and exhibiting leakage of photosynthetic pigments. Fig. 2 shows that after approximately $40 \mathrm{~min}$ of treatment phycobilins started to be released reaching the maximum after $50 \mathrm{~min}$ in the extracellular medium of the Anabaena P-9 culture, indicating a release of phycobilins from the thylakoids. Phycocyanins and allophycocyanins were released nearly simultaneously. No detectable release of chlorophylls was detected, even up to $120 \mathrm{~min}$ after treatment.

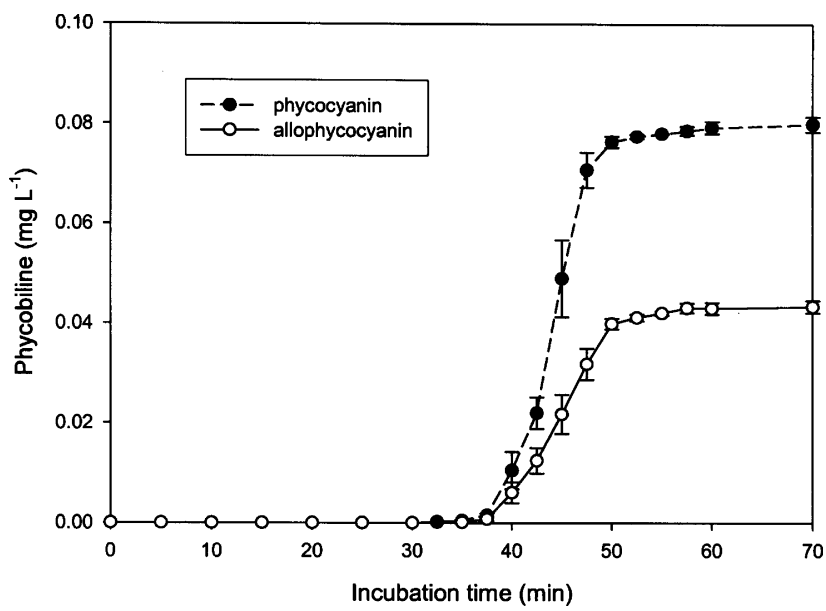

Fig. 2. Time courses of phycocyanin- and allophycocyanin-leakages in Anabaena P-9 cells (cell density $11.4 \pm 0.4 \mu \mathrm{g} \mathrm{chl} \mathrm{mL}^{-1}$ ) under the treatment with $0.359 \mathrm{mmol} \mathrm{L}^{-1} \tilde{\alpha}$-linolenic acid. 


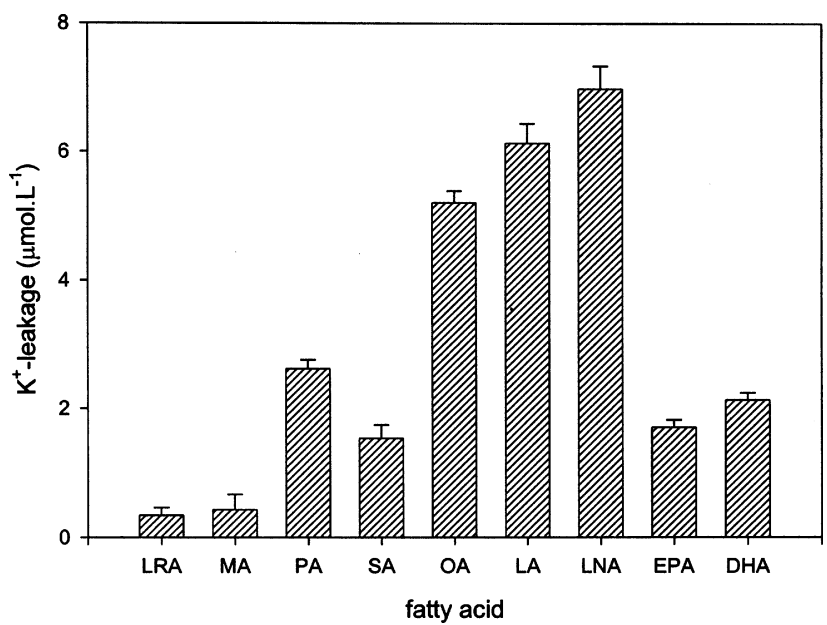

Fig. 3. Magnitude of $\mathrm{K}^{+}$-leakage from Monoraphidium contortum cells resulted from treatment with various kinds of fatty acids for a culture density of $8.5 \pm 1.5 \mu \mathrm{g} \mathrm{chl} \mathrm{mL}^{-1}$. The treated dose of fatty acid for lauric acid (LRA): $0.497 \mu \mathrm{mol} \mathrm{L}^{-1}$; myristic acid (MA): $0.438 \mu \mathrm{mol} \mathrm{L}^{-1}$; palmitic acid (PA): $0.390 \mu \mathrm{mol} \mathrm{L}^{-1}$; stearic acid (SA): $0.352 \mu \mathrm{mol} \mathrm{L}^{-1}$; oleic acid (OA): $0.354 \mu \mathrm{mol} \mathrm{L}^{-1}$; linoleic acid (LA): $0.357 \mu \mathrm{mol} \mathrm{L}^{-1}$; alpha-linolenic acid (LNA): $0.359 \mu \mathrm{mol} \mathrm{L}^{-1}$; eicosapentaenoic acid (EPA): $0.331 \mu \mathrm{mol} \mathrm{L}^{-1}$; docosahexaenoic acid (DHA): $0.304 \mu \mathrm{mol} \mathrm{L}^{-1}$. The values are mean \pm SD. $n=3$.

\subsection{Relationship between fatty acid toxicity and magnitude of $K^{+}$leakage}

The levels of $\mathrm{K}^{+}$leakage differed with the kind of fatty acids tested. For $M$. contortum, higher levels occurred for $\mathrm{C}_{18}$ fatty acids (OA, LA, and LNA), followed by PA, then SA, EPA, and DHA; LRA and MA were less effective in causing $\mathrm{K}^{+}$leakage (Fig. 3). A plot of the magnitude of the released $\mathrm{K}^{+}$concentrations against toxicity (i.e., $\mathrm{EC}_{50}$ of fatty acids for growth inhibition of C. vulgaris and M. contortum) shows that they are negatively correlated, with $R^{2}=0.809$ (Fig. 4).

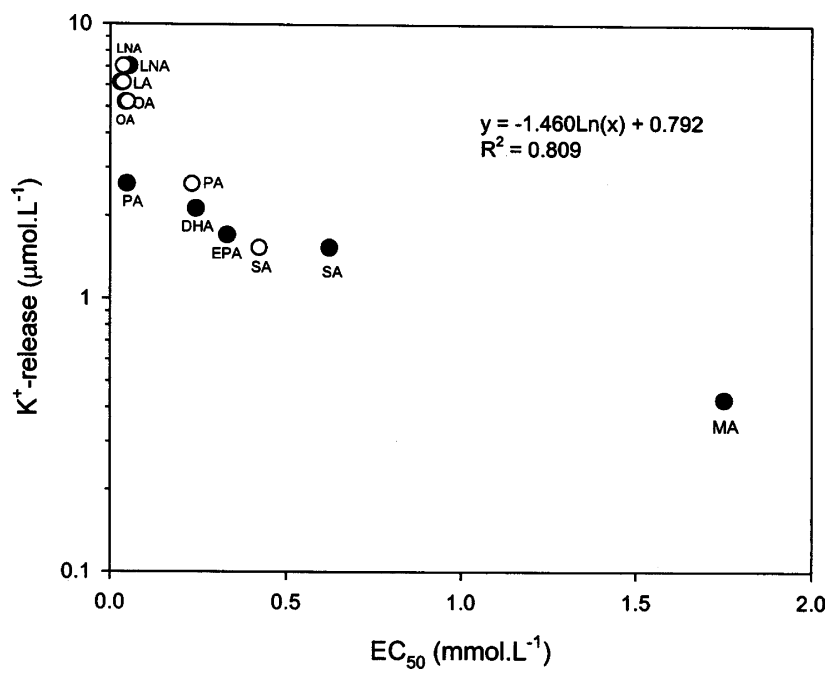

Fig. 4. The levels of $\mathrm{K}^{+}$-leakage as the function of the magnitude of the median inhibition concentrations of various fatty acids (abbreviations see the text) for the growth of Monoraphidium contortum (filled) and Chlorella vulgaris (blank) cells. The abbreviations of fatty acids see Fig. 3 .

\subsection{Ultrastructural changes in cellular organization due to fatty acid treatment}

Under the culture conditions, both the filamentous and the single-celled forms of Anabaena P-9 coexisted in cultures. TEM observations did not reveal any significant difference in the intracellular organization between either cell type (Fig. 5A and B). When Anabaena P-9 cells were treated with $0.178 \mu \mathrm{mol} \mathrm{L}^{-1} \mathrm{LA}$ (i.e., the $\mathrm{EC}_{50}$ for its growth), remarkable changes were observed in their cellular organization, particularly in the cell outer membranes. During $\mathrm{K}^{+}$leakage in the first $15 \mathrm{~min}$ of treatment, no visible change in the ultrastructure of cellular organization of the vegetative cells occurred. However, a disruption of the cell outer membranes (i.e., plasmalemmae) occurred after $30 \mathrm{~min}$ (Fig. 5C, indicated by arrowhead), giving rise to the lysis of certain cells. Consequently, numerous freely released thylakoids were observed (indicated by arrow in Fig. 5C). The lysis of the stressed cells occurred prior to the release of phycobilins, which began to occur at approximately $60 \mathrm{~min}$ after treatment (cf. Fig. 4).

During treatment with deleterious concentrations of fatty acids, certain vegetative cells were not lysed (Fig. 5D). These cells did not show any remarkable change in their cellular organization, except that the appearance of tiny granules in the inter-thylakoid space changed. In control cells, numerous tiny granules (with diameter $<15 \mathrm{~nm}$ ) existed (cf. Fig. 5A). After treatment, numerous larger granules (approximate diameter $30 \mathrm{~nm}$ ) appeared in the thylakoid lamellae in the cells that eventually not lysed (cf. Fig. 5E). The appearance of such granules was more evident after 120 min of treatment (Fig. 5F).

Compared to the vegetative cells, the heterocyst was more resistant to fatty acid treatment. During treatment, heterocyst disruption was not observed until $60 \mathrm{~min}$ after exposure. Fig. 6A shows that the heterocyst remained when the vegetative cells had lysed. Lysis of the heterocyst was observed when the treatment with fatty acid was prolonged (Fig. 6B). However, the thick wall of the heterocyst was not lysed by fatty acid treatment; it remained intact after the cell membranes had been lysed (Fig. 6C and D).

When treated with sublethal doses of LA (i.e., $<\mathrm{EC}_{50}$ ), only a portion of Anabaena P-9 cells was lysed (Fig. 6C). However, nearly all of the treated cells lysed when the treatment dose was doubled (Fig. 6D). Thus, a positive correlation exists between the degree of cell lysis and the toxicity of fatty acids.

\section{Discussion}

\subsection{Membrane damage as a mode of action of fatty acids}

The toxic effects of allelochemicals on phytoplankton are usually manifold and can include an inhibitory effect on the electron transport of photosynthesis (Venediktov and Krivoshejeva, 1983; Warden and Csatorday, 1987). However, the primary effects relate to a disorganization of the functional integrity of the membrane (Hedrich and Schroeder, 1989). Herein we report that fatty acids exert an effect on cell plasma membranes, which results in a rapid alteration in permeability associated with $\mathrm{K}^{+}$ 

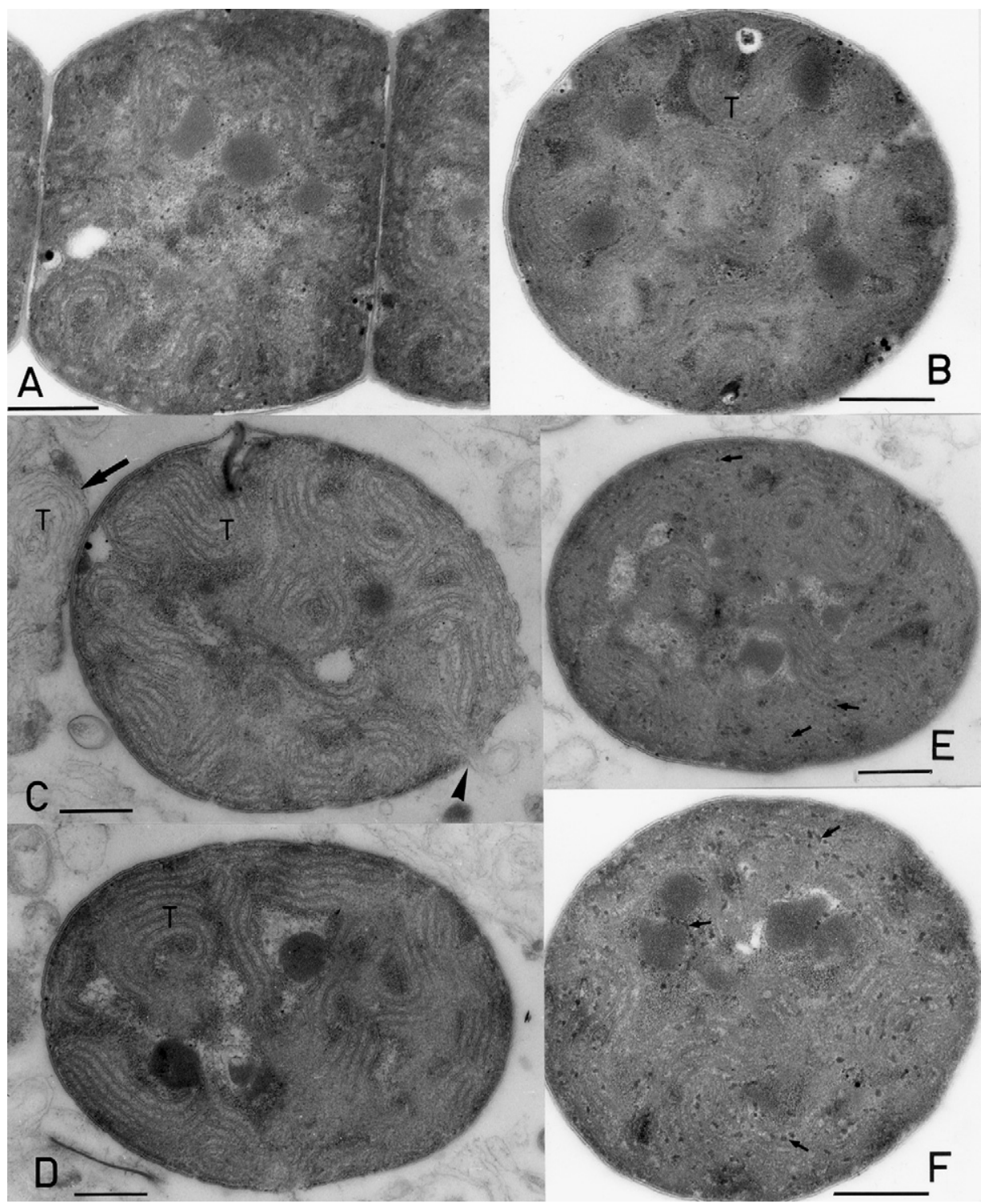

Fig. 5. Changes in ultrastructure of Anabaena P-9 cells during treatment with $0.178 \mu \mathrm{mol} \mathrm{L}^{-1}$ linoleic acid (LA). (A) The controlled vegetative cells in a filament; (B) single controlled vegetative cell; (C) 30 min after treatment, showing disruption of plasma membranes (arrowhead) and released thylakoids (arrow) from the lysed cell; (D) cell resistant to LA treatment, compared to the lysed cellular fragments (arrow); (E) 60 min after LA treatment of not lysed cell, showing tiny granules appeared in the inter-thylakoid space; (F) 120 min after LA treatment, showing increased number and size of granules (arrow). T: thylakoid membranes. Bars $=500 \mu \mathrm{m}$.

leakage and the subsequent breakdown of membrane organization. These findings suggest that a primary mechanism of action of deleterious fatty acids is damage to plasma membranes.

Certain allelochemicals, such as sesquiterpenoid from Gymnodinium nagasakiense (Kajiwara et al., 1992) or the allelopathic substance produced by Peridinium aciculiferum (Rengefors and Legrand, 2001), have been shown to cause cell lysis of target organisms. In both cases, cell blistering occurred before lysis. In the present study, neither cell form nor cell size changed much before cell disruption occurred. Thus, the mechanism of action of the fatty acids used in this study might be different from that of sesquiterpenoid and the allelopathic substance of $P$. aciculiferum.

Kakisawa et al. (1988) reported that tetra-unsaturated fatty acids such as $(5 Z, 8 Z, 11 Z, 14 Z)$-eicosatetraenoic acid or $(6 \mathrm{Z}, 9 \mathrm{Z}, 12 \mathrm{Z}, 15 \mathrm{Z})$-octadecatetraenoic acid produced by a brown alga, Cladosiphon okamuranus, caused cell destruction of a flagellate of Rhaphidophyceae, Heterosigma akashiwo. However, they did not further study the toxic effect of these fatty acids. The cytotoxic effect of these polyunsaturated fatty acids is unclear.

\section{2. $K^{+}$leakage as an indicator of membrane damage}

Leakage of $\mathrm{K}^{+}$as a response to damage to cell membranes occurs in a variety of organisms, including Candida albicans when treated with polyene antibiotics (Hammond et al., 1974); lichen when fumigated with ozone (Holopainen and Oksanen, 1997); Spodoptera frugiperda when in contact with toxic peptide (Guihard et al., 2001); and Anacystis nidulans when exposed to heavy metals (Wu et al., 1995). Such a response appears to be a common phenomenon of cells under stress. In this study, the levels of leaked $\mathrm{K}^{+}$varied with the kinds of fatty acids tested 


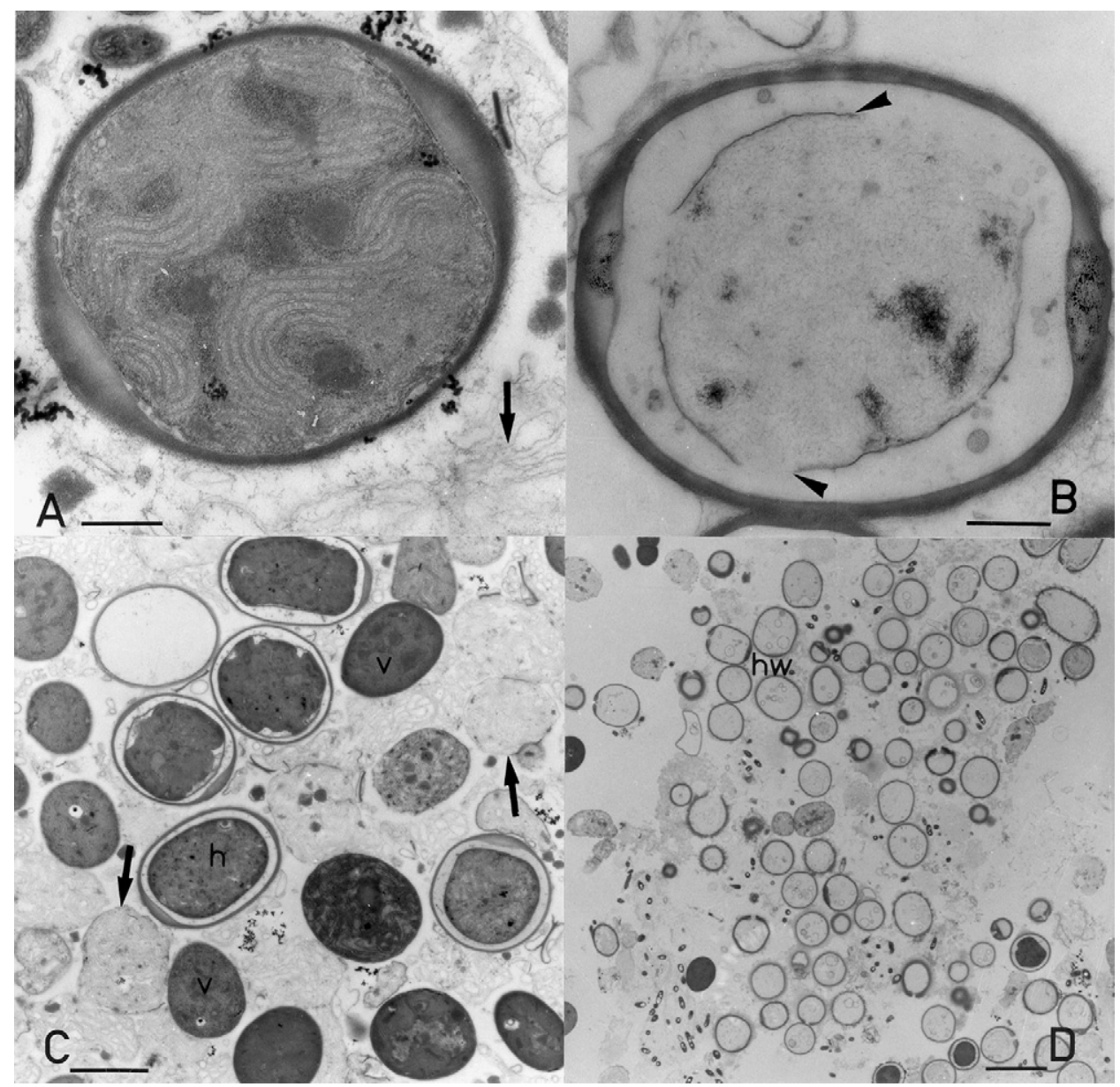

Fig. 6. Changes in ultrastructure of heterocysts of Anabaena P-9 cells during treatment with $0.178 \mu \mathrm{mol} \mathrm{L}^{-1}$ LA. (A) Sixty minutes after treatment, showing a morphologically unchanged heterocyst surrounded by numerous thylakoids released from the lysed vegetative cell; (B) 120 min after treatment, showing disruption (indicated by arrowheads) of the plasma membrane of a heterocyst; (C) $120 \mathrm{~min}$ after treatment with $0.178 \mu \mathrm{mol} \mathrm{L}^{-1} \mathrm{LA}$, showing a portion of the lysed cells (arrow), not lysed vegetative cells (v) and the heterocyst (h); (D) $120 \mathrm{~min}$ after treatment with $0.357 \mu \mathrm{mol} \mathrm{L}^{-1} \mathrm{LA}$, showing lysis of almost all kinds of cells and the empty heterocyst wall (hw). Bar $=500 \mu \mathrm{m}$ for (A) and (B), bar $=2 \mu \mathrm{m}$ for $(\mathrm{C})$, and $\mathrm{bar}=10 \mu \mathrm{m}$ for (D).

and displayed a positive correlation with the susceptibility of target organisms to fatty acids. The level of $\mathrm{K}^{+}$leakage likely is related to the degree of damage in the membranes and thus could be used as a physiological indicator of toxic effects.

Schmitt et al. (1999) considered the leakage of ions to be a result of irreparable damage to the plasma membrane in the form of enzymatic hydrolysis or pore formation. By studying the hemolytic activity of prymnesin, a toxin produced by Prymnesium parvum, Igarashi et al. (1996) deduced that the toxin acted directly on cell membranes through cation pore formation. In a study of maitotoxin, a polyether toxin produced by dinoflagellates, Igarashi et al. (1999) referred to an effect of the toxin on potent haemolytic activity through activation of $\mathrm{Ca}^{2+}$ channel, which caused $\mathrm{Ca}^{2+}$ influx and the activation of calmodulin and thus the promotion of phospholipase A2 activity. As a consequence, the cells disrupted due to hydrolysis of membrane lipids. In the present study, however, the leakage of $\mathrm{K}^{+}$occurred so rapidly that it could be detected almost immediately after treatment with fatty acids. Thus, it is also possible that such a rapid change is attributed to a direct effect of fatty acids on the membranes rather than through an involvement of phospholipase A2 enzyme. In order to ascertain this, a further study is necessary.

Sokolov et al. (1999) proposed that exposure to fatty acids might cause a change in the ultrastructure of the membranes or the formation of an ion channel in the planar phospholipid bilayers, thus, giving rise to an alteration in membrane permeability. The lipid composition of plasma membranes is highly variable. Plant and algal plasma membranes contain lipids such as palmitic acid, linoleic acid, and linolenic acid. The results of this study show that the phytoplankton species tested were more sensitive to these fatty acids than to others. Presumably, these fatty acids might interact more easily with plasma membranes to result in an alteration in membrane conformation.

In this study, higher levels of $\mathrm{K}^{+}$leakage occurred when the algae were exposed to fatty acids with higher levels of unsaturation in the C-chain. This agrees with the observations of McCracken et al. (1980), who found that most inhibitory effects resulted from exposure to unsaturated fatty acids. Kakisawa et al. (1988) also found that the toxicity of fatty acids increased 
with an increase in the number of unsaturated double bonds. Unsaturated fatty acids were oxidized to form hydroxyl compounds and displayed anti-algal activity in the study by Aliotta et al. (1990). Despite these findings, it is still unclear whether the damage to membranes results from the fatty acid itself or from its oxidized hydroxyl compounds. A further study is necessary to clarify this issue.

\subsection{Release of pigment}

We reported the release of phycobilins in response to toxic substances in our previous study with Microcystis aeruginosa, in which we treated it with the water-soluble extracts of Peridinium bipes, a freshwater dinoflagellate (Wu et al., 1998). In that study, we observed that the plasma membranes and the cellular organization were distorted and disrupted prior to the release of phycobilins. We observed a similar scenario in the present study when we treated Anabaena P-9 cells with fatty acids. It is noteworthy that during the release of phycobilin molecules, no release of chlorophylls was detected, although both pigments are associated with the thylakoids of the tested cells. Possibly, such a difference can be attributed to the way each pigment binds to the thylakoids: phycobilins bind to the outer surface of the thylakoid membranes (Glazer, 1982), whereas chlorophylls are integral proteins of the thylakoid membranes. As a result, the former is more easily released than the latter when the cells are exposed to fatty acids.

\subsection{Microenvironment for expression of toxic effects of fatty acids}

In the present study, deleterious effects were observed when the test algae were exposed to high concentrations of fatty acids. Such high concentrations rarely occur in the natural environment, but certain algae produce a considerable quantity of fatty acids (Chiang et al., 2004) and might discharge them into the surrounding aquatic environment, particularly when an algal bloom occurs. Most fatty acids are hydrophobic and not very soluble in water. They tend to form small micelles to increase their solubility in water, like many other lipophilic compounds (Fischer et al., 1994; Perez and Martin, 2001). Micelles would easily stick to the cell surface of target organisms, form a highconcentration microenvironment there, and penetrate into the hydrophobic regions of the cell membranes. Thus, it is possible for hydrophobic fatty acids to exert toxic effects in the aquatic environment.

Our previous study showed that the susceptibility of phytoplankton to fatty acids varied from species to species (Chiang et al., 2004). As a rule, species possessing only a thin mucilage layer displayed higher susceptibility to fatty acids than those with a thick mucilage layer outside the cell wall. The mucilage is composed mainly of polysaccharides, which are more or less hydrophilic. Possibly, the mucilage layer of phytoplankton acts as a protectant by preventing the cells from having direct contact with hydrophobic fatty acids.

In conclusion, the present study showed that free fatty acids exerted cytotoxic effects on the plasma membranes of some species of phytoplankton, resulting in an alteration in membrane permeability. Damage to the plasma membranes allowed $\mathrm{K}^{+}$to leak out from the cellular interior. These findings suggest that the lethal effects of fatty acids may be caused by the lytic effect on the stressed cells, via disruption of the cell plasma membranes. As a secondary effect, fatty acids seem to cause the dissociation of phycobilins from the thylakoid membranes.

\section{Acknowledgement}

This work was supported by a grant from the National Science Council of Taiwan (NSC 90-2311-B-001-015).

\section{References}

Aliotta, G., Della Greca, M., Monaco, P., Pinto, G., Pollio, A., Previtera, L., 1990. In vitro algal growth inhibition by phytotoxins of Typha latifolia L. J. Chem. Ecol. 16, 2637-2646.

Bennett, A., Bogorad, L., 1973. Complimentary chromatic adaptation in a filamentous blue-green alga. J. Cell Biol. 58, 419-435.

Cembella, A.D., 2003. Chemical ecology of eukaryotic microalgae in marine ecosystems. Phycologia 42, 420-447.

Chiang, I.Z., 2002. The toxicity of metabolites of Botryococcus braunii from Lake Li-Yu. Master Thesis. Nat. Taiwan Univ., Taipei, Taiwan.

Chiang, I.Z., Huang, W.Y., Wu, J.T., 2004. Allelochemicals of Botryococcus braunii (Chlorophyceae). J. Phycol. 40, 474-480.

Cohen, W.S., Nathanson, B., White, J.E., Brody, M., 1969. Fatty acids as model systems for the action of Ricinus leaf extract on higher plant chloroplasts and algae. Arch. Biochem. Biophys. 135, 21-27.

Einhellig, F.A., 2001. The physiology of allelochemical action: clues and views. In: Reigosa, M.J., Bonjoch, N.P. (Eds.), Physiological Aspects of Allelopathy. Proceedings of the First European Symposium. Vigo, Spain, pp. 3-25.

Entzeroth, M., Mead, D.J., Patterson, G.M.L., Moore, R.E., 1985. A herbicidal fatty acid produced by Lyngbya aestuarii. Phytochemistry 24, 2875 2876.

Fischer, N.H., Williamson, G.B., Weidenhamer, J.D., Richardson, D.R., 1994. In search of allelopathy in the Florida scrub-the role of terpenoids. J. Chem. Ecol. 20, 1355-1380.

Friend, J., Hawcroft, D.M., 1967. Carotenoids and fatty acids as uncoulpers of photophosphorylation in isolated chloroplasts. Biochem. J. 104, 60.

Glazer, A.N., 1982. Phycobilisomes: structure and dynamics. Ann. Rev. Microbiol. 36, 173-198.

Gross, E.M., 2003. Allelopathy of aquatic autotrophs. Crit. Rev. Plant Sci. 22, 313-339.

Guihard, G., Laprade, R., Schwartz, J.T., 2001. Unfolding affects insect cell permeabilization by Bacillus thuringiensis Cry $1 \mathrm{C}$ toxin. Biochim. Biophys. Acta 1515, 110-119.

Hammond, S.M., Lambert, P.A., Kliger, B.N., 1974. The mode of action of polyene antibiotics: induced potassium leakage in Candida albicans. J. Gen. Microbiol. 81, 325-330.

Hedrich, R., Schroeder, J.I., 1989. The physiology of ion channels and electrogenic pumps in higher plants. Ann. Rev. Pl. Physiol. Pl. Mol. Biol. 40, 539-569.

Holopainen, T., Oksanen, J., 1997. Ultrastructural changes and electrolyte leakage from ozone fumigated epiphytic lichens. Ann. Bot. 80, 611-621.

Igarashi, T., Aritake, S., Yasumoto, T., 1999. Mechanisms underlying the hemolytic and ichthyotoxic activities of maitotoxin. Natural Toxins 7, 71-79.

Igarashi, T., Satake, M., Yasumoto, T., 1996. Prymnesin-2: a potent ichthyotoxic and hemolytic glycoside isolated from the red tide alga Prymnesium parvum. J. Am. Chem. Soc. 118, 479-480.

Ikawa, M., Haney, J.F., Sasner, J.J., 1996. Inhibition of Chlorella growth by the lipids of cyanobacterium Microcystis aeruginosa. Hydrobiologia 331, $167-170$. 
Jüttner, F., 2001. Liberation of 5,8,11,14,17-eicosapentaenoic acid and other polyunsaturated fatty acids from lipids as a grazer defense reaction in epilithic diatom biofilms. J. Phycol. 37, 744-755.

Kajiwara, T., Ochi, S., Kodama, K., Matsui, K., Hatanaka, A., Fujimara, T., Ikeda, T., 1992. Cell-destroying sesquiterpenoid from red tide of Gymnodinium nagasakienese. Phytochemistry 31, 783-785.

Kakisawa, H., Asari, F., Kusumi, T., Toma, T., Sakurai, T., Oohusa, T., Hara Y., Chihara, M., 1988. An allelopathic fatty acid from the brown alga Cladosiphon okamuranus. Phytochemistry 27, 731-735.

Kamaya, Y., Kurogi, Y., Suzuki, K., 2003. Acute toxicity of fatty acids to the freshwater green alga Selenastrum capricornutum. Environ. Toxicol. 18, 289-294.

Keating, K.I., 1977. Allelopathic influence on blue-green bloom sequence in a eutrophic lake. Science 196, 885-887.

Keating, K.I., 1978. Blue-green algal inhibition of diatom growth: transition from mesotrophic to eutrophic community structure. Science 199, 971-973.

Kuhl, A., 1962. Zur Physiologie der Speicherung kondensierter anorganischer Phosphate in Chlorella. Vort. Gesamtgeb. Bot. 1, 157-166.

Legrand, C., Rengefors, K., Fistarol, G.O., Graneli, E., 2003. Allelopathy in phytoplankton: biochemical, ecological and evolutionary aspects. Phycologia 42, 406-419.

McCracken, M.D., Middaugh, R.E., Middaugh, R.S., 1980. A chemical characterization of an algal inhibitor obtained from Chlamydomonas. Hydrobiologia 70, 271-276.

Mundt, S., Kreitlow, S., Jansen, R., 2003. Fatty acids with antibacterial activity from the cyanobacterium Oscillatoria redekei HUB 051. J. Appl. Phycol. $15,263-267$.

Ohta, S., Shiomi, Y., Kawashima, A., Aozasa, O., Nakao, T., 1995. Antibiotic effect of LNA from Chlorococcum strain HS-101 and Dunaliella primolecta on methicillin-resistant Staphylococcus aureus. J. Appl. Phycol. 7, 121-127.
Perez, E., Martin, D.F., 2001. Critical micelle concentrations of allelopathic substances produced by Nannochloris oculata which affect a red tide organism, Gymnodinium breve. Cytobios 106, 163-170.

Rengefors, K., Legrand, C., 2001. Toxicity in Peridenium aciculiferum-an adaptive strategy to outcompete other winter phytoplankton? Limnol. Oceanogr. 46, 1990-1997.

Schmitt, C.K., Meysick, K.C., O'Brien, A.D., 1999. Bacterial toxins: friends or foes? Emerg. Infect. Dis. 5, 1-6.

Siegenthaler, P.-A., 1973. Change in $\mathrm{pH}$ dependence and sequential inhibition of photosynthetic activity in chloroplasts by unsaturated fatty acids. Biochim. Biophys. Acta 305, 153-162.

Sokolov, Y., Mirzabekov, T., Martin, D.W., Lehrer, R.I., Kagan, B.L., 1999. Membrane channel formation by antimicrobial protegrins. Biochim. Biophys. Acta 1420, 23-29.

Spruell, J.A., 1984. Response to algae and zooplankton to $\mathrm{C}_{18}$ fatty acids of Chlamydomonas reinhardtii. Hydrobiologia 114, 9-12.

Suzuki, M., Wakana, I., Denboh, T., Tatewaki, M., 1996. An allelopathic polyunsaturated fatty acid from red algae. Phytochemistry 43, 63-65.

Todorova, A., Jüttner, F., 1996. Ecotoxicological analysis of nostocyclamide, a modified cyclic hexapeptide from Nostoc. Phycologia 35 (Suppl. 6), 183-188.

Venediktov, P.S., Krivoshejeva, A.A., 1983. The mechanisms of fatty-acid inhibition of electron transport in chloroplasts. Planta 159, 411-414

Warden, J.T., Csatorday, K., 1987. On the mechanism of linolenic acid inhibition in photosystems II. Biochim. Biophys. Acta 890, 215-223.

Wu, J.T., Chang, S.C., Chen, K.S., 1995. Enhancement of intracellular proline level in cells of Anacystis nidulans (Cyanobacteria) exposed to deleterious concentrations of copper. J. Phycol. 31, 376-379.

Wu, J.T., Kuo-Huang, L.L., Lee, J., 1998. Algicidal effect of Peridinium bipes on Microcystis aeruginosa. Curr. Microbiol. 37, 257-261. 